\title{
EFFECT OF SOME CHEMICAL TREATMENTS AND HAND DEFOLIATION ON WINTER PRODUCTION AS YIELD, FRUIT QUALITY AND STORAGE LIFE OF GUAVA
}

El-Baz, El. El. T.*; M. A. El-Shobaky*; A. A. Lo'ay* and M. A. A. Saleh**

* Hort. Dept.. Faculty of Agriculture, Mansoura University, Egypt.

** Hort. Res. Inst., ARC, Giza, Egypt.

\begin{abstract}
The present investigation was conducted during 2008 and 2009 seasons on common seedy guava trees grown in a private orchard at EL kefah village, Badr center Behera governorate to study the effects of different treatments of defoliation on tree yield and fruit quality at harvest time as well as loss in weight, decay and total loss during storage at room temperature as represent of marketing conditions of guava trees. All tested treatments gave significant increase in fruit quality(fruit weight, firmness, total sugars contents, vitamin c, acidity, SSC and SSC/ acid ratio), in both seasons of the study as compared with control. Both control fruits at the normal harvest period in the summer were held at $20-22{ }^{\circ} \mathrm{C}$ and $\mathrm{RH} 75 \%$ and fruits of other treatments were held at $12-14{ }^{\circ} \mathrm{C}$ and $\mathrm{RH} 82 \%$ at the winter season of harvest period in the winter. The obtained data indicated that urea 10\% gave significant increase in yield of winter crop as compared with other treatments. In addition $\mathrm{ZnSO}_{4} 2 \%+$ $\mathrm{NH}_{4} \mathrm{NO}_{3} 4 \%$ gave significant improvement in fruit quality as compared with other treatments. Concerning fruits held at room temperature, $\mathrm{ZnSO}_{4} 2 \%+\mathrm{NH}_{4} \mathrm{NO}_{3} 4 \%$ showed significant increase in in fruit quality (fruit weight, firmness, total sugars, vitamin c, acidity, SSC and SSC/ acid ratio) and gave the lowest weight loss after 9 days of room storage. Concerning control fruits (summer yield) the data indicated significant increase in yield, but a decrease in their quality and an increase in fruit weight loss and decay, due to fruits harvested in early dates in summer. The decay reached $100 \%$ after 3 days due to increased summer temperature. The winter crop of guava fruit trees from these treatments were good quality and its high price covered greatly the reduction in yield.
\end{abstract}

\section{INTRODUCTION}

Guava fruits is one of the most common fruits in Egypt. It is popular for all people due to its cheap price compared with other fruits at same time, norishing value and good taste. It is also a rich and cheap source for vitamin $\mathrm{C}$ and contains about 2 to 5 times higher than fresh orange juice and as a good source of both calcium and phosphorus (Phandis , 1970 and Siddiqui et al., 1991). It is also rich in pectins, which has industrial uses for jelly production ( Bose and Mitra, 1990 ).

The summer season crop of guava fruits were exposed to many pests and diseases (Pena et al.,2002), This causes great losses to the growers because the fruits are unmarketable. In addition to that crop fruits have a cheap price and storability is very short due to fruits are being affected with high temperature in the summer season, which causes browning colour of guava fruit , fast decay and its short shelf life to their fruits. 
In Egypt, guava trees were forced to produce their fruits in winter season as affected by some agricultural practices as preventing totally irrigation water for four months to help defoliation starting from April , ploughed, fertilized and then irrigated at first of August.

Most of winter production of guava fruits are exported to other countries, so improving productivity and fruit quality is important issue to earn more commercial advantages for growers. Besides, guava fruits are desired to local market and aboard in winter. In addition to introducing a new approach of pruning, irrigation, fertilization and defoliation, also the use of different safe compounds as Urea, NAA and ethephon has been extensively applied to guava trees in vigorous vegetative growth to change yield patterns ( Shigeura et al., 1975 and Singh et al., 1991 ) work on guava has been mainly limited to urea , NAA and ethephon (Gorakh et al., 2000 ).

\section{The objective of this study is:}

1- To turn the summer crop of guava to late crop to obtain fruits of a good quality and to prolong shelf life and marketing field of fruits that it suitable for marketability and export.

2- Help farmer in new reclamation land to obtain high satisfied price guava crop.

\section{MATERIALS AND METHDOS}

The present investigation was carried out during the two successive seasons 2007 / 2008 and 2008 / 2009 on common seedy guava trees to study the effect of some chemical substances for stimulating winter crop of guava and extending the storage life of the fresh fruit. In this study, the selected trees were 11- year-old growing in a private orchard at EL Kefah village, Badr center, EL Behera Governate, Egypt.

Sixty three guava trees were planted at a spacing of $5 \times 5 \mathrm{~m}$ apart in sandy soil under drip irrigation system and received similar cultural practices commonly adopted in that area. The selected trees were almost uniform as possible as concern with their vigour and nearly free from diseases.

During two seasons, fifty four trees were selected at random for spraying with different concentrations of tested chemicals and other nine trees were sprayed with tap water as control. The experiment was designed as a complete randomized blocks with three trees in each replicate. Yet all treatments included control trees were represented in three replicates.

In this study the trees were prevented from irrigation water for four months (First April until end July) to help defoliation.

The treatments were applied as follows:

$\begin{array}{lll}1- & \text { Urea } & 10 \% \\ 2- & \text { Urea } & 15 \% \\ 3- & \text { Naphthaleneacetic acid } & 400 \mathrm{ppm} \\ 4- & \text { Ethephon } & 1200 \mathrm{ppm} \\ 5- & \mathrm{ZnSO}_{4}++\mathrm{NH}_{4} \mathrm{NO}_{3} & \mathrm{ZnSO}_{4} \%+\mathrm{NH}_{4} \mathrm{NO}_{3} 4 \% \\ 6- & \text { Hand defoliation } & \\ 7- & \text { Control ( untreated trees ) } & \text { Spray with tap water }\end{array}$


The treatments from number ( 1 to 5 ) mixed with $0.1 \%$ super film surfactant as a wet agent. All treatments were applied to plant as foliar spraying one time at the end of July in both seasons 2008-2009.

Concerning untreated fruit were control harvested mid September; the other treatments were harvested first March.The selected fruits were almost of equal volume and fruits free from insect infection and pathogen injury.

\section{Fruit physical properties such as:}

Fruit characteristics were determined at harvest and during storage.

1- Fruit weight (g.).

2- Fruit firmness ( $\mathrm{lb} / \mathrm{inch}^{2}$.) measured by using penetrometer (Effegi hand held, facchini, ALfonsine, Italy) fitted with a plunger $8 \mathrm{~mm}$ diameter according to (Watkins and Harmani, 1981).

\section{Fruit chemical properties such as:}

1-Titratable Acidily (\%. ), five $\mathrm{ml}$ sample of fruit juice was used to determine the titratable acidity by the titration aganist $0.1 \mathrm{~N}$ sodium hydroxide in the presence of phenolphthalein as an indicator according to (A.O.A.C.1980). (Total titrable acidity was expressed as $\mathrm{mg}$ citric acid $/ 100 \mathrm{ml}$ Juice).

2-Vitamin C content ( $\mathrm{mg} / 100 \mathrm{ml}$ Juice ), $5 \mathrm{ml}$ samples of fruit Juice were used, $5 \mathrm{ml}$ of oxalic acid solution added to each sample and titrated with 2,6 dichloro - phenol - indophenol dye solution (A.OA.C.1980)..

3-Total sugar content (\%) described by (Sadasivam and Manickam1996).

4-Soluble solids content (SSC \%). Soluble solids content in Fruit Juice was measured by using a Carlzeiss hand referctometer according to (Chen and Mellenthin, 1981).

5-(SSC / acid ratio)

One carton box for each treatment was taken at 3 days intervals to determine the loss in fruit weight, decayed fruits, total loss and changes in fruit quality during storage for 9 days.

\section{Statistical analysis:}

Data of both seasons of the study were statistically analyzed by using complete randomized block design as described by Snedecor and Cochran, 1973. Differences among treatment means were compared by using the least significant differences test (LSD) at $5 \%$ level of probability.

\section{RESULTS AND DISCUSSION}

\section{Yield (kg):}

Data in Table 1 cleared that yield in all treatments significantly decreased in two seasons compared with control. It is obvious from Table 1 that chemical treatment by urea $10 \%$ gave high yield $(66.27-68.63 \mathrm{~kg})$ in booth seasons of the study (2008 and 2009), respectively, comparing with other chemical treatments and followed by ethephon treatment with (61.17$61.53 \mathrm{Kg})$, urea $15 \%$ with $(58-59.45 \mathrm{Kg})$, hand defoliation with $(54.25-54.79$ $\mathrm{kg}$ ) per tree in two seasons of study and least yield obtained by NAA 400 ppm it reached (32.29-32.94 kg) per tree. The results concerning the control and chemical treatment by Urea $10 \%$ on yield are in agreement with those 
obtained by several investigators (Shigeura et al.; 1975; Gorakh et al.; 2000; Sanjay et al., 2004; Dimple et al.,2005; and Mohammed, et al., 2006) who found that spraying urea at $10 \%$ gave significantly higher yield.

Data in Table 1 indicate that NAA applications at $(400 \mathrm{ppm})$ gave significant decrease on yield/tree this result may be due to NAA at concentration $(400 \mathrm{ppm})$ reduced fruit set of guava trees. These results are confirmed with those reported by Choudhary et al., (1997) who found that NAA $(200,250$ or $300 \mathrm{ppm})$ reduced fruit set in the rainy season crop of guava.

Table (1): Effect of different treatments of defoliation on guava tree yield (kg) during two seasons of study.

\begin{tabular}{|c|c|c|}
\hline \multirow{2}{*}{ Treatments } & \multicolumn{2}{|c|}{ Yield/tree(kg) } \\
\hline & $2007 / 2008$ & $2008 / 2009$ \\
\hline Hand def. & 54.25 & 54.79 \\
\hline NAA 400ppm & 32.29 & 32.94 \\
\hline Urea $10 \%$ & 66.27 & 68.63 \\
\hline Urea 15\% & 58.00 & 59.45 \\
\hline $\mathrm{ZnSO}_{4} 2 \%+\mathrm{NH}_{4} \mathrm{NO}_{3} 4 \%$ & 54.32 & 56.50 \\
\hline ETH1200ppm & 61.17 & 61.53 \\
\hline control & 86.00 & 87.17 \\
\hline L.S.D at $5 \%$ & 2.19 & 2.23 \\
\hline
\end{tabular}

\section{Fruit Weight (g):}

Results shown in Table 2 stated that significant increasing and revealed that treatment of $\mathrm{ZnSO}_{4}+\mathrm{NH}_{4} \mathrm{NO}_{3}$ were gained the greatest fruit weight comparing with control which recorded an average of both seasons (197.00g) compared with control (154.25g)

\section{Firmness (lb/ in $\left.{ }^{2}\right)$ :}

It is evident from Table 2 that, during the two seasons of this study the firmness of guava fruits significantly increased by applied $\mathrm{ZnSO}_{4}+\mathrm{NH}_{4} \mathrm{NO}_{3}$ and NAA ranged between (8.95-9.17 and 8.53-8.73 $\left.\mathrm{lb}_{\mathrm{in}}{ }^{2}\right)$ in (2008 and

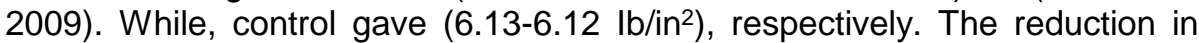
fruit firmness for control (summer crop) reflect the effect of high temperature in the summer season that accelerate ripening processes of their fruits. All treatments maintained firmness is good firmness status because fruit ripening occurred in low temperature during harvest time in winter season. These results are in agreement with those obtained by Mecrardo et al., (1998) and Bariana and Dhaliwal(2002).

It was observed that fruit firmness decreased with storage time, as the rate of degradation of insoluble protopectins to simple soluble pectins, increased with the progress of storage time.

Total sugars content (\%):

The results presented in Table 3 indicated that reducing sugar significantly increased by $\mathrm{ZnSO}_{4}+\mathrm{NH}_{4} \mathrm{NO}_{3}$ and NAA in two seasons of study, where reached (4.87-4.99\%) and (4.75-8.84\%) in (2008 and 2009) seasons respectively. 
J. Plant Production, Mansoura Univ., Vol. 2 (3), March, 2011 
Concerning to non-reducing sugars, Table 3 show that $\mathrm{ZnSO}_{4}+\mathrm{NH}_{4} \mathrm{NO}_{3}$, NAA and ethephon had the same trend of those noticed with that of the reducing sugars. Spraying $\mathrm{ZnSO} 4+\mathrm{NH}_{4} \mathrm{NO}_{3}$ may be help in fruit development due to efficient synthesis of organic compounds that increased in SSC and accumulation of reducing and non reducing sugars. The obtained data are in line with those found by Arora and singh (1970). According to Table 3, concerning the effect of all treatments on total sugars of guava fruits, the results showed that this data took nearly the same trend of that noticed with both reducing and non reducing sugars. The above mentioned results are nearly similar to those obtained by Das et al., (2000) who found that the effects of spraying zinc sulfate $(0.5$ or $1.0 \%)$ aqueous solution increased the total, reducing, and non reducing sugar contents of guava fruits.

Vitamin C ( $\mathrm{mg} / \mathbf{1 0 0} \mathrm{ml}$ juice):

Determination of Vitamin C (ascorbic acid) content in fruits juice of guava at harvest time indicated that $\mathrm{ZnSO}_{4}+\mathrm{NH}_{4} \mathrm{NO}_{3}$ had an promoting effect on this characteristic if compared with the other treatments and control in the two seasons as shown in Table 4 with value of V.C (123.74 to 124.98 $\mathrm{mg} / 100 \mathrm{ml}$ juice) in (2008 and 2009), respectively. Application of $\mathrm{ZnSO}_{4}$ was based on the study of Tripathi, (2006) who found that pre-harvest spray of zinc sulfate at 0.4 percent improved ascorbic acid contents in guava fruits.

Acidity (\%):

Data tabulated in Table 4 showed that hand defoliation, ethephon and control lead to decrease of acidity compared with other treatments used. These finding are in line with those reported by Arora, and Singh, (1970) who found that foliar spray zinc sulphate at $0.0 \%, 0.2 \%$ and $0.4 \%$ significantly reduced the time of fruit maturity which due to more hastened fruit development and earliness in maturity and significant reduction acidity of guava might be due to accumulation of reducing and non reducing sugars.

\section{Soluble solids content(SSC):}

Data in Table 5 concerning the effect of different practices applied on guava trees indicated that spraying ethephon and $\mathrm{ZnSO} 4+\mathrm{NH} 4 \mathrm{NO} 3$ significantly increased SSC in guava fruits during the two seasons of this study. Both treatments produced fruit with god quality of SSC compared with all other tested treatments and control. Patt and Goesch; (1969) reported that ehtylene may be a casual agent of changes in cell permeability that occur during the maturation and ripening of fruits. Also, added that ethylene stimulates respiration and protein synthesis in certain immature fruits which may tigger a chain of biochemical events of enzyme protein occurs early during the ripening process.

\section{The SSC/Acid ratio:}

Table 5 showed clearly that, all applications in this investigation effected on the SSC/acid ratio almost in a similar way that noticed with SSC/acid ratio which referees to the relation between the SSC and acidity on the values of the SSC/acid ratio were obtained by dividing the former on the later. Urea $10 \%$ application gave generally the least values of SSC/acid ratio while both $\mathrm{ZnSO}_{4}+\mathrm{NH}_{4} \mathrm{NO}_{3}$, ethephon and control produced fruits with highest SSC/acid ratio. 
J. Plant Production, Mansoura Univ., Vol. 2 (3), March, 2011

$3-4$ 


\section{Fruit weight loss\%:}

Table 6 revealed that weight loss percentage increased during room storage. The weight loss is resulted in a water loss from fruit tissue and partially due to respiration processes. Data in the same Table showed that the fruit from treatments of NAA, hand defoliation and $\mathrm{ZnSO}_{4}+\mathrm{NH}_{4} \mathrm{O}_{3}$ gave the lowest physiological loss in weight after 9 days of room storage, they reached (6.09-6.29),(7.16-7.33)and(8.55-8.71) respectively in two seasons of study. The above results are in agreement with those obtained by Dhoot et al.,(1984); Chandra(1995) chaitany et al.,(1997); Saraswathi and Zhakia manavalan,(1997); Malaviya and Sirothia., (2001) and Samant et al., (2008).

Fruit Decay\%:

Data in Table 6 clearly showed that, fruit decay percentage significantly increased in control because fruits harvested in summer. The value of decay reached (81.34-76.56) in two seasons after 3 days of room storage. The value of decay after 3 days in control reached (100\%) in two seasons at room storage. The fruits in control are held at room conditions of $20-22{ }^{\circ} \mathrm{C}$ due to the time of appear crops of guava fruits. High temperature caused rapid browning of fruits and granulation became serious and the commercial quality of the fruits fastly declined. All treatments without control [harvest in late dates on winter] gave values of decay (Zero \%) after 6 days at room storage. Also, there were significant increased in decay by ethephon treatment the data were ranged about (85.22-87.22) in two seasons after 9 days at room storage. The results were in line with those reported by Brown,(1983) Lertpuk and Mendoza (1988); Chen and Zhang (2001); Bassetto et al., (2005); Golding et al., (2005); Rogachev (2007) and Sachin et al., (2009).

Total loss of guava fruits \%:

It is obvious from Table 6 that the total loss including loss of fruit weight and loss due to decay were significantly increase at the end of storage period. In connection with the other authers, Brown (1983) storage fruit of guava at $10^{\circ} \mathrm{C}$ extended post harvest life about 2 week. Adel A. Kader (2006) recommended temperature $8-10^{\circ} \mathrm{C}$ for mature partially-ripe guavas (storage potential 2-3 weeks) and optimum relative humidity (90-95\%). From the same Table it is clear that loss percent age due to decaying organisms was the chief factor caused the highest total loss $\%$ in guava fruits after 9 days of room storage. In general, the data obtained from this study revealed that remove leaves by hand or by chemical treatments specially using $\mathrm{ZnSO} 4+\mathrm{NH} 4 \mathrm{O} 3$ or NAA help farmer to obtained late yield of guava fruits (in winter). These treatments improve fruit quality, also decreased total loss percentage and then shelf life for guava fruits is high that is suitable for market ability and export. The fruits of guava in winter crop is high price covered greatly the reduce in the yield. 
J. Plant Production, Mansoura Univ., Vol. 2 (3), March, 2011

$5-6$

475 


\section{REFERENCES}

A.O.A.C.(1980). Official Methods of Analysis. $13 \mathrm{Ed}$ Association official analysis chemist. Washington, D.C., USA.

Adel, A. Kader. (2006). Guava recommendations for maintaining postharvest quality.Dep. of PI. Sci. Univ.

Arora, J. S. and J. R. Singh, (1970). Some effect of foliar spray of zinc sulphate on growth, yield and fruit quality of guava Psidium guajava L.). College of Agriculture, Banaras Hindu Univ., Varanas $1-5$, India.

Bariana, D. and G. S. Dhaliwal, (2002). Effect of chemicals on the fruit quality and yield of winter season crop guava ( Psidium guajava L.) cv.Sardar J. Res.,Punjab, Agric. Univ., 39 (4) : 508 - 512.

Bassetto, E. ; A. P. Jacomino, ; A. L. Pinheiro, and R. A. Kluge, (2005). Delay of ripening of pedro sato guava with 1- methyl cyclopropene.Post harvest Biology and Technology., 35: $303-308$.

Bose, T. K. and S. K. Mitra, (1990). Guava in fruit subtropical.Bose (Ed.) Nayaprakash.

Brown, B. I. (1983). Post -harvest of guava. Australian Hort. Res. News letter, (55) : $152-153$.

Chaitany, C. G. ; G. Kumar,; B. L. Raina, and A. K. Muthoo, (1997). Effect of zinc and boron on the shelf life of guava cv.Sardar (Psidium guajava L.) Advances in plant Sciences., 10 (2): 45 - 49.

Chandra, R. (1995). Biochemical changes during maturity and storage in guava fruits. Ind. of Hill farming., 8 (1) : $16-21$.

Chen, P. K. and W. M. Mellenthin, (1981). Effect of harvest date on ripening capacity and post - harvest life of Anjou pears J. Amer. Soc. Hort. Sci., $106: 138$.

Chen, W. H. and F. P. Zhang, (2001). The formal and physiological changes of guava fruits during post harvest storage. Plant physiology Communications., 37 (1): $25-26$.

Choudhary, R. ; U. P. Singh, and R. K. Sharma, (1997). Crop regulation in guava cv. Lucknow-49. Orissa, J.Hort., 25 (1):10 - 13.

Das, A.; K. Majumder, and B. C. Mazumdar, (2000). Zinc sulphate induced higher sweetness of rainy season guava fruits. Indian Agri.44 (3/4): $199-201$.

Dhoot, L. R.; U.T. Desai, and D. A. Rane, (1984). Studies on the shelf life of guava fruits with polyethylene packaging and chemical treatments. J. Maharashata, Agriculture .Universities., 9 ( 2 ) : 185 - 188.

Dimple, B.; G. S. Dhaliwal, and J. S. Bal, (2005). Effect of chemicals on foliage characters, flower drop, fruit set and yield of rainy season crop of guava cv.sardar . Haryana J.Hort.Sci.34 (1/2): 14-15.

Golding, J. B.; J. H. Ekman, and W. B. McGlasson, (2005). Regulation of fruit ripening. Steward post harvest Review., 3: 1-2.

Gorakh, S.; A. K. Singh, and V. Ajay (2000). Economic evaluation of crop regulation treatments in guava (Psidium guajava). Ind. J. of Agric. Sci., 70(4): 226-230.

Lertpuk, S. and D. B. Mendoza, (1988). Post - harvest life of carabas mango (Mangifera indica L.)as affected by pre- harvest treatment of ethephon. Phlippine Agriculturist.,71 : 1,1-5. 
Malaviya, P. K and N. N. Sirothia, (2002). Post-harvest handling damage in guava.New -Agriculturist., 13 (1/2) 35-40.

Mecardo,S.; B. P. Ebenito, and M. A. G. Valasco, (1998). Fruit development, harvest index and ripening changes of guava as produced in central Mexico.Post Harvest Biology and Technology.,13 (2) : 143 - 150.

Mohammed, S.; J. R. Sharma; R. Kumar,; R. Pal, and S. Singh (2006). Effect of different chemical on cropping pattern and quality of guava cv.Sardar.Haryana J.Hort.Sci.,35 (3/4): 226-227.

Patt, H. K. and J. D. Goesch, (1969). Physiological roles of ethylene in plants.Ann.Rev.Plant physiol., 20: $541-584$.

Pena, J. E.; J. L. Sharp, and M. Wysoki, (2002). Tropical fruit pests and pollinates: biology economic importance, natural enemies and control.Wallingford. UK.CABI.Publishing VII, 430 PP. ISBNO., 85199 434- 2. (Hort. Abst., 72: 10531).

Phandis, N. A. (1970). Physic - Chemical composite fruits. Ind. J. Hort., 27 : $417-433$.

Rogachev, M. A. (2007). Effect of ammonium nitrate application time on apple productivity, quality and shelf life. Sadovodstvo vinogradarstvo., $6,8-9$.

Sachin, P.; S. Ganesh,; D. K. Varu, and R. R. Viradia, (2009). Effect of post harvest treatments on physiological characters of mango cv.KESAR during storage.Asian Journal of Horticulture., 4: 1,141 - 144.

Sadasivam, S. and A. Manickam, (1996). "Biochemical Methods", $2^{\text {nd }}$ Ed. New age international India.

Samant, D.; N. K. Mishra, A. K. Singh and R. L. Lai, (2008). Effect of micronutrient sprays on fruit yield and quality during storage inbred cv. Umran under ambient conditions., Ind. J. Hort. 65 (4).

Sanjay, S. and K. Naresh, (2004). Crop regulation and quality control in guava (Psidium guajava L.).Progr.Hort., 36 (1): 152-154.

Saraswathi, T. and R. S. Azhakiamanavalan, (1997). Post - harvest studies to increases shelf life of mandarin orange. South Indian Horticulture., $45:(3 / 4), 95-98$.

Sendecor, W. G. and Cochran (1973). Statistical Methods 6th ED. The Lowa State Univ.Press,Ames,Lowa,USA.

Shigeura, G. T.; R. M. Bullock, and J. A. Silva, (1975). Defoliation fruit set in guava. Hort. Since., 10(6):590.

Siddiqui, S. R. K. Sharma, and O. P. Gupta,(1991). Physiological and quality response of guava fruits to posture during shelf life. Hort. Sci., 26: 1295 $-1297$.

Singh, G.; S. Rajan,; D. Panely, and A. K. Singh, (1991). Annual report of central Institute for subtropical Horticulture, Lucknow., pp. $13-18$.

Tripathi, V. K. (2006). Influence of pre- harvest spray of mineral nutrients on the storage behaviour of guava (Psidium guajava L.) cv.Sardar fruits. J. Asian Hort., 2(3):201-204.

Watkins,C. and I. Haramani, (1981). Use of penetrometer to measure flesh firmness of fruit. Orchandist, N.Z.,54: $14-16$. 
EI-Baz, EI. EI. T. et al.

تأثير بعض المعاملات الكيميائية و ازالة الاوراق باليد على انتاج محصول جوافة شتوى و على القدرة التحزينية للثمار.

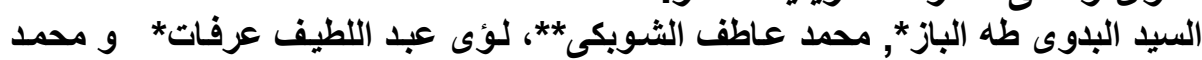

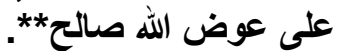

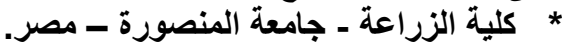

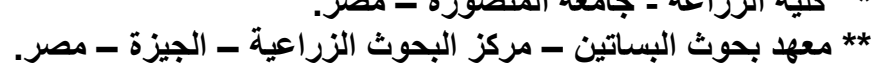

أجرى هذا البحث لدراسة تاثير المعاملات الكيميائية و ازالة الاوراق باليد على أشجار جو افة عادية

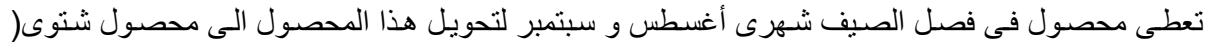

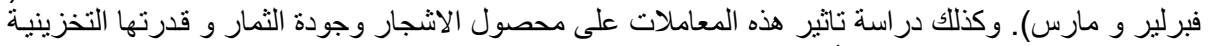

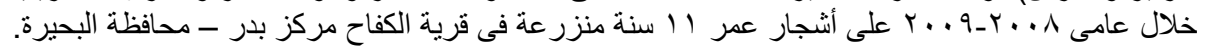

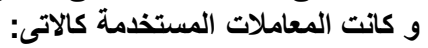

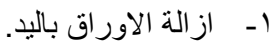

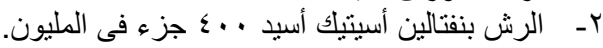

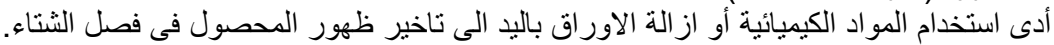

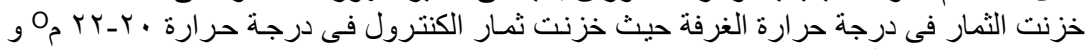

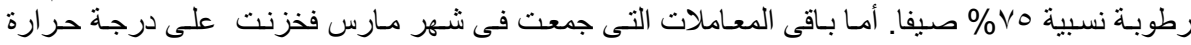

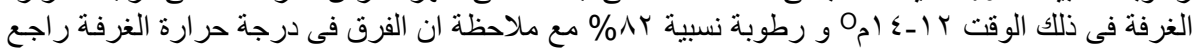

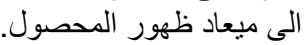

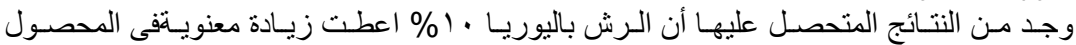

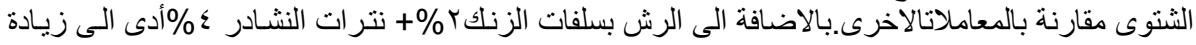

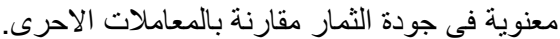

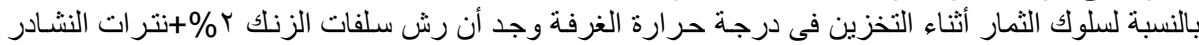

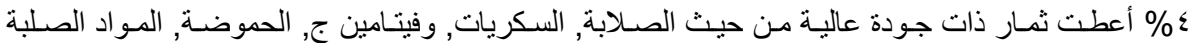

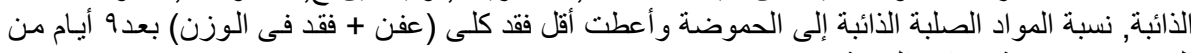
التخزين فى درجة حرارة الغرفة.

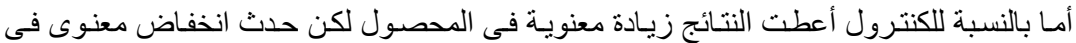

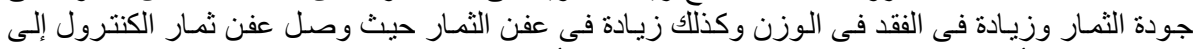

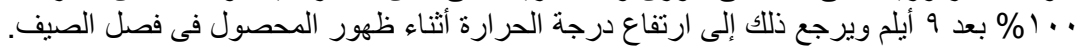

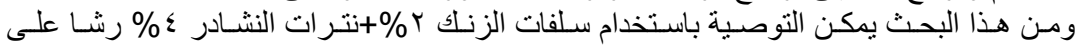

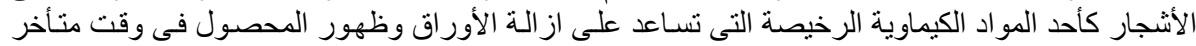

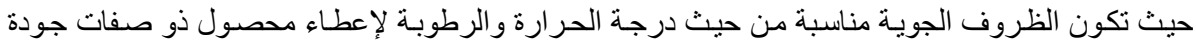

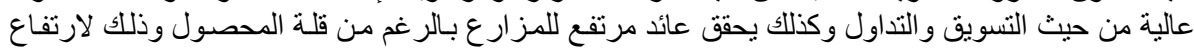
سعر الثمار فى ذلك الوقت من العام (الثتاء) إلى جانب قلثة الفقد فى الوزن الثن وكذلك قلة نسبة الثمار التالفة.

كلية الزراعة - جامعة المنصورة كلية الزراعة - جامعة الاسكندريه
أ.د / أد محسن فهمى محمد مصطقى أ. أد / عو اد محمد حسين معين 
J. Plant Production, Mansoura Univ., Vol. 2 (3), March, 2011 

Table (2): Effect of different treatments of defoliation on fruit weight (g) and firmness (lb/ $\left.\mathrm{in}^{2}\right)$ of guava fruits shelf life under room temperature during two seasons of study.

\begin{tabular}{|c|c|c|c|c|c|c|c|c|c|c|c|c|c|c|c|c|}
\hline \multirow{4}{*}{ Treatments } & \multicolumn{8}{|c|}{ Fruit weight (g) } & \multicolumn{8}{|c|}{ Firmness $\left(\mathrm{lb} / \mathrm{in}^{2}\right)$} \\
\hline & \multicolumn{4}{|c|}{$2007 / 2008$} & \multirow{2}{*}{\multicolumn{4}{|c|}{$\begin{array}{l}\text { 2008/2009 } \\
\text { Period in days }\end{array}$}} & \multicolumn{4}{|c|}{$2007 / 2008$} & \multicolumn{4}{|c|}{\begin{tabular}{|l|}
$2008 / 2009$ \\
\end{tabular}} \\
\hline & \multirow{2}{*}{ 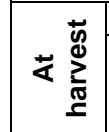 } & \multicolumn{3}{|c|}{ Period in days } & & & & & \multirow{2}{*}{ 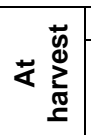 } & \multicolumn{3}{|c|}{ Period in days } & \multirow{2}{*}{ 这 } & \multicolumn{3}{|c|}{ Period in days } \\
\hline & & 3 & 6 & 9 & 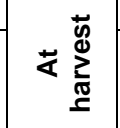 & 3 & 6 & 9 & & 3 & 6 & 9 & & 3 & 6 & 9 \\
\hline Hand def. & 156.18 & 156.56 & 153.33 & 151.66 & 160.16 & 162.03 & 155.55 & 153.86 & 7.93 & 6.54 & 5.47 & 3.41 & 8.12 & 6.69 & 5.59 & 3.49 \\
\hline NAA 400ppm & 165.90 & 164.73 & 168.40 & 157.87 & 168.80 & 168.86 & 171.75 & 161.01 & 8.53 & 7.30 & 6.48 & 3.92 & 8.73 & 7.56 & 7.15 & 4.01 \\
\hline Urea 10\% & 174.40 & 166.73 & 171.80 & 163.80 & 179.63 & 170.90 & 175.84 & 167.65 & 8.49 & 7.51 & 6.67 & 3.60 & 8.46 & 7.70 & 6.24 & 3.86 \\
\hline Urea 15\% & 177.90 & 168.53 & 168.40 & 156.10 & 182.26 & 172.75 & 173.08 & 160.44 & 8.21 & 7.14 & 6.04 & 3.88 & 8.65 & 7.36 & 6.82 & 3.71 \\
\hline $\mathrm{ZnSO}_{4} 2 \%+\mathrm{NH}_{4} \mathrm{NO}_{3} 4 \%$ & 194.62 & 163.42 & 171.00 & 160.83 & 199.39 & 167.50 & 175.75 & 165.30 & 8.95 & 7.46 & 7.02 & 4.34 & 9.17 & 7.64 & 5.92 & 4.45 \\
\hline ETH1200ppm & 178.10 & 172.07 & 160.40 & 155.00 & 182.46 & 176.37 & 164.86 & 159.31 & 7.51 & 6.79 & 5.74 & 2.90 & 7.76 & 7.02 & 6.64 & 3.00 \\
\hline Control & 153.71 & 148.71 & - & - & 154.79 & 152.17 & - & - & 6.13 & 5.78 & - & - & 6.12 & 5.55 & - & - \\
\hline L.S.D at $5 \%$ & 3.595 & 10.062 & 12.525 & 3.038 & 3.675 & 10.638 & 12.842 & 3.112 & 0.298 & 0.739 & 0.124 & 0.248 & 0.298 & 0.739 & 1.024 & 0.248 \\
\hline
\end{tabular}

Table (3): Effect of different treatments of defoliation on reducing sugars(\%), Non reducing sugar(\%) and total sugars $(\%)$ in guava fruits shelf life during two seasons of study.

\begin{tabular}{|c|c|c|c|c|c|c|c|c|c|c|c|c|c|c|c|c|c|c|c|c|c|c|c|c|}
\hline \multirow[b]{4}{*}{ Treatments } & \multicolumn{8}{|c|}{ Total sugar\% } & \multicolumn{8}{|c|}{ Non reducing sugar $\%$} & \multicolumn{8}{|c|}{ Reducing sugar \% } \\
\hline & \multirow{2}{*}{\multicolumn{4}{|c|}{$\begin{array}{l}2007 / 2008 \\
\text { Period in davs }\end{array}$}} & \multirow{2}{*}{\multicolumn{4}{|c|}{\begin{tabular}{|l|}
$2008 / 2009$ \\
Period in days \\
\end{tabular}}} & \multirow{2}{*}{\multicolumn{4}{|c|}{\begin{tabular}{|l|l|}
$2007 / 2008$ \\
& Period in days \\
\end{tabular}}} & \multirow{2}{*}{\multicolumn{4}{|c|}{ 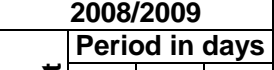 }} & \multirow{2}{*}{\multicolumn{4}{|c|}{\begin{tabular}{|c|c|}
\multicolumn{2}{|c|}{$2007 / 2008$} \\
& Period in days \\
\end{tabular}}} & \multirow{2}{*}{\multicolumn{4}{|c|}{\begin{tabular}{|c|c|}
\multicolumn{2}{|c|}{$2008 / 2009$} \\
\multirow{2}{*}{ Period in days } \\
\end{tabular}}} \\
\hline & & & od in & days & & & & & & & & & & & & & & & & & & & & \\
\hline & 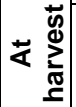 & 3 & 6 & 9 & « & 3 & 6 & 9 & 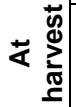 & 3 & 6 & 9 & 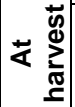 & 3 & 6 & 9 & 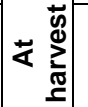 & 3 & 6 & 9 & 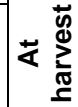 & 3 & 6 & 9 \\
\hline Hand def. & 5.92 & 6.62 & 7.02 & 8.52 & 6.04 & 6.75 & 7.16 & 8.69 & 1.21 & 1.26 & 1.02 & 1.19 & 1.23 & 1.29 & 1.04 & \begin{tabular}{|l|}
1.21 \\
\end{tabular} & 4.715 & 5.36 & 6.00 & 7.33 & 4.80 & 5.47 & 6.12 & 7.48 \\
\hline NAA & 6.04 & 6.70 & 7.45 & 8.69 & 6.16 & 6.83 & 7.60 & 8.86 & 1.29 & 1.28 & 1.32 & 1.28 & 1.32 & 1.31 & 1.35 & \begin{tabular}{|c|}
1.31 \\
\end{tabular} & 4.75 & 5.42 & 6.13 & 7.41 & 4.84 & 5.52 & 6.24 & 7.55 \\
\hline & 5.82 & 6.45 & 7.22 & 8.41 & 5.92 & 6.56 & 7.35 & 8.56 & 1.25 & 1.23 & 1.37 & 1.21 & 1.31 & 1.30 & 1.44 & 1.29 & 4.575 & 5.22 & 5.85 & 7.20 & 4.62 & 5.27 & 5.91 & 7.27 \\
\hline Urea 15\% & 5.71 & 6.40 & 7.10 & 8.31 & 5.81 & 6.51 & 7.23 & 8.46 & 1.26 & 1.33 & 1.39 & 1.25 & 1.31 & 1.39 & 1.46 & \begin{tabular}{|l|}
1.33 \\
\end{tabular} & 4.455 & 5.07 & \begin{tabular}{|l|}
5.71 \\
\end{tabular} & 7.07 & 4.49 & 5.12 & 5.77 & 7.14 \\
\hline \begin{tabular}{|l|}
$\mathrm{ZnSO}_{4}$ \\
$\mathrm{NH}_{4} \mathrm{NO}_{3} 4 \%$
\end{tabular} & 6.17 & 6.79 & 7.50 & 8.81 & 6.32 & 6.96 & 7.69 & 9.03 & 1.30 & 1.25 & 1.28 & $\mid 1.26$ & 1.33 & 1.28 & 1.31 & 1.29 & $4.87 \mid 5$ & 5.54 & 6.22 & 7.55 & 4.99 & 5.68 & 6.38 & 7.74 \\
\hline ETH1200ppm & 5.58 & 6.23 & 6.89 & 8.14 & 5.66 & 6.32 & 6.99 & 8.25 & 1.35 & 1.32 & $1.27 \mid$ & 1.20 & 1.39 & 1.36 & 1.31 & 1.24 & $4.23 \mid$ & 4.91 & 5.62 & 6.94 & 4.27 & 4.96 & 5.68 & 7.01 \\
\hline Control & 5.33 & 6.40 & - & - & 5.44 & 7.51 & - & - & 1.04 & 1.18 & - & - & 1.10 & 1.38 & - & - & 4.305 & 5.22 & - & - & 4.34 & 6.13 & - & - \\
\hline L.S.D at $5 \%$ & 0.203 & 0.169 & 0.404 & 0.086 & 0.209 & 0.196 & 0.410 & \begin{tabular}{|l|}
0.087 \\
\end{tabular} & 0.236 & 0.152 & 0.385 & 0.081 & \begin{tabular}{|l|}
0.239 \\
\end{tabular} & 0.160 & 0.393 & \begin{tabular}{|l|}
0.083 \\
\end{tabular} & 0.1200 & 0.148 & \begin{tabular}{|l|}
0.072 \\
\end{tabular} & 0.082 & 0.124 & 0.145 & 0.073 & 0.082 \\
\hline
\end{tabular}


Table (4): Effect of different treatments of defoliation on Vitamin C ( $\mathrm{mg} / 100 \mathrm{ml}$ juice) and Acidity (\%) in guava fruits shelf life during two seasons of study.

\begin{tabular}{|c|c|c|c|c|c|c|c|c|c|c|c|c|c|c|c|c|}
\hline \multirow{4}{*}{ Treatments } & \multicolumn{8}{|c|}{ Vitamin C (mg/100 ml juice) } & \multicolumn{8}{|c|}{ Acidity (\%) } \\
\hline & \multicolumn{4}{|c|}{$2007 / 2008$} & \multicolumn{4}{|c|}{$2008 / 2009$} & \multicolumn{4}{|c|}{$2007 / 2008$} & \multicolumn{4}{|c|}{$2008 / 2009$} \\
\hline & \multirow[b]{2}{*}{ 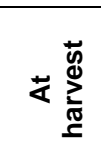 } & \multicolumn{3}{|c|}{ Period in days } & \multirow[b]{2}{*}{ 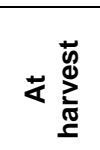 } & \multicolumn{3}{|c|}{ Period in days } & \multirow[b]{2}{*}{ 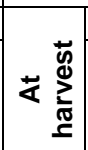 } & \multicolumn{3}{|c|}{ Period in days } & \multirow[b]{2}{*}{ 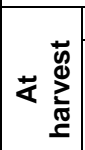 } & \multicolumn{3}{|c|}{ Period in days } \\
\hline & & 3 & 6 & 9 & & 3 & 6 & 9 & & 3 & 6 & 9 & & 3 & 6 & 9 \\
\hline Hand def. & 111.45 & 108.04 & 99.37 & 90.78 & 114.24 & 105.40 & 96.95 & 93.05 & 0.49 & 0.47 & 0.43 & 0.38 & 0.48 & 0.46 & 0.43 & 0.38 \\
\hline NAA 400ppm & 117.19 & 113.05 & 108.83 & 95.46 & 119.54 & 110.83 & 106.69 & 97.37 & 0.50 & 0.48 & 0.44 & 0.39 & 0.50 & 0.49 & 0.44 & 0.39 \\
\hline Urea 10\% & 116.25 & 110.64 & 105.56 & 94.68 & 118.10 & 108.90 & 103.90 & 96.19 & 0.48 & 0.46 & 0.42 & 0.37 & 0.47 & 0.45 & 0.42 & 0.37 \\
\hline Urea $15 \%$ & 115.65 & 111.33 & 104.31 & 93.52 & 117.49 & 109.58 & 102.67 & 95.00 & 0.50 & 0.47 & 0.43 & 0.38 & 0.50 & 0.47 & 0.43 & 0.38 \\
\hline $\mathrm{ZnSO}_{4} 2 \%+\mathrm{NH}_{4} \mathrm{NO}_{3} 4 \%$ & 123.74 & 117.06 & 110.90 & 100.76 & 124.98 & 115.90 & 109.80 & 101.77 & 0.51 & 0.49 & 0.45 & 0.40 & 0.49 & 0.47 & 0.45 & 0.40 \\
\hline ETH1200ppm & 113.85 & 110.18 & 103.41 & 92.76 & 116.49 & 107.69 & 101.07 & 94.91 & 0.53 & 0.51 & 0.47 & 0.42 & 0.53 & 0.51 & 0.47 & 0.42 \\
\hline \begin{tabular}{|l|} 
Control \\
\end{tabular} & 97.90 & 93.76 & - & - & 100.17 & 91.43 & - & - & 0.43 & 0.40 & - & - & 0.42 & 0.39 & - & - \\
\hline L.S.D at $5 \%$ & 2.424 & 1.834 & 1.771 & 0.454 & 0.248 & 1.966 & 1.741 & 0.462 & 0.007 & 0.01 & 0.01 & 0.01 & 0.007 & 0.01 & 0.01 & 0.006 \\
\hline
\end{tabular}

Table (5): Effect of different treatments of defoliation on SSC (\%) and SSC/acid ratio (\%) in guava fruits shelf life during two seasons of study.

\begin{tabular}{|c|c|c|c|c|c|c|c|c|c|c|c|c|c|c|c|c|}
\hline \multirow{4}{*}{ 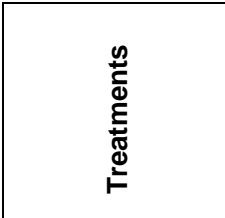 } & \multicolumn{8}{|c|}{$\operatorname{SSC}(\%)$} & \multicolumn{8}{|c|}{ SSC/acid ratio (\%) } \\
\hline & \multicolumn{4}{|c|}{ 2007/2008 } & \multicolumn{4}{|c|}{ 2008/2009 } & \multicolumn{4}{|c|}{$2007 / 2008$} & \multicolumn{4}{|c|}{$2008 / 2009$} \\
\hline & \multirow{2}{*}{ 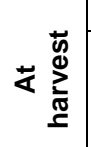 } & \multicolumn{3}{|c|}{ Period in days } & \multirow{2}{*}{ 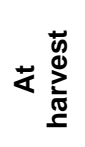 } & \multicolumn{3}{|c|}{ Period in days } & \multirow{2}{*}{ 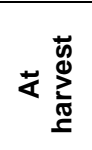 } & \multicolumn{3}{|c|}{ Period in days } & \multirow{2}{*}{ 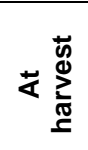 } & \multicolumn{3}{|c|}{ Period in days } \\
\hline & & 3 & 6 & 9 & & 3 & 6 & 9 & & 3 & 6 & 9 & & 3 & 6 & 9 \\
\hline Hand def. & 10.53 & 11.07 & 12.60 & 14.33 & 10.78 & 11.32 & 12.89 & 14.66 & 21.35 & 23.38 & 29.07 & 37.38 & 22.45 & 24.61 & 29.79 & 38.31 \\
\hline NAA 400ppm & 10.66 & 11.19 & 12.72 & 14.46 & 11.01 & 11.56 & 13.15 & 14.94 & 21.45 & 23.16 & 28.70 & 36.75 & 22.24 & 23.75 & 29.70 & 38.04 \\
\hline Urea $10 \%$ & 11.12 & 11.65 & 13.18 & 14.92 & 11.40 & 11.95 & 13.52 & 15.29 & 23.01 & 25.58 & 31.64 & 40.68 & 24.08 & 26.35 & 32.49 & 41.78 \\
\hline Urea 15\% & 10.94 & 11.47 & 13.00 & 14.74 & 11.28 & 11.83 & 13.41 & 15.20 & 21.69 & 24.58 & 30.48 & 39.12 & 22.41 & 25.17 & 31.48 & 40.42 \\
\hline $\begin{array}{l}\mathrm{ZnSO} 4 \\
2 \%+\mathrm{NH}_{4} \mathrm{NO}_{3} 4 \%\end{array}$ & 11.85 & 12.38 & 13.91 & 15.65 & 12.08 & 12.62 & 14.18 & 15.95 & 23.20 & 25.44 & 31.15 & 39.44 & 24.65 & 26.66 & 31.79 & 40.27 \\
\hline ETH1200ppm & 10.72 & 11.25 & 12.78 & 14.52 & 10.97 & 11.51 & 13.08 & 14.85 & 20.10 & 22.06 & 27.20 & 34.56 & 20.83 & 22.72 & 27.87 & 35.41 \\
\hline Control & 9.81 & 11.03 & - & - & 10.03 & 12.22 & - & - & 23.09 & 26.91 & - & - & 23.70 & 31.33 & - & - \\
\hline L.S.D at $5 \%$ & 0.415 & 0.277 & 0.228 & 0.231 & 0.426 & 0.376 & 0.236 & 0.236 & 0.581 & 0.521 & 0.69 & 0922 & 0.82 & 1.398 & 0.739 & 0.985 \\
\hline
\end{tabular}


J. Plant Production, Mansoura Univ., Vol. 2 (3), March, 2011

Table (6): Effect of different treatments of defoliation on loss in weight (\%),Decay (\%) and Total loss (\%)in guava fruits shelf life during two seasons of study

\begin{tabular}{|c|c|c|c|c|c|c|c|c|c|c|c|c|c|c|c|c|c|c|c|c|c|c|c|c|}
\hline \multirow{4}{*}{ Treatments } & \multicolumn{8}{|c|}{ Loss in Weight (\%) } & \multicolumn{8}{|c|}{ Decay (\%) } & \multicolumn{8}{|c|}{ Total Loss (\%) } \\
\hline & \multicolumn{4}{|c|}{ 2007/2008 } & \multicolumn{4}{|c|}{$2008 / 2009$} & \multicolumn{4}{|c|}{$2007 / 2008$} & \multicolumn{4}{|c|}{ 2008/2009 } & \multicolumn{4}{|c|}{$2007 / 2008$} & \multicolumn{4}{|c|}{$2008 / 2009$} \\
\hline & \multirow{2}{*}{ 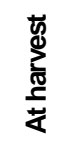 } & \multicolumn{3}{|c|}{ Period in days } & \multirow{2}{*}{ 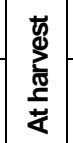 } & \multicolumn{3}{|c|}{ Period in days } & \multirow{2}{*}{ 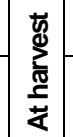 } & \multicolumn{3}{|c|}{ Period in days } & \multirow{2}{*}{ 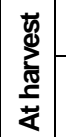 } & \multicolumn{3}{|c|}{ Period in days } & \multirow{2}{*}{ 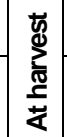 } & \multicolumn{3}{|c|}{ Period in days } & \multirow{2}{*}{ 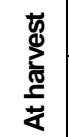 } & \multicolumn{3}{|c|}{ Period in days } \\
\hline & & 3 & 6 & 9 & & 3 & 6 & 9 & & 3 & 6 & 9 & & 3 & 6 & 9 & & 3 & 6 & 9 & & 3 & 6 & 9 \\
\hline Hand def. & 0.00 & 5.50 & 7.25 & 7.16 & 0.00 & 5.50 & 7.26 & 7.33 & 0.00 & 0.00 & 0.00 & 78.02 & 0.00 & 0.00 & 0.00 & $\mid 79.82$ & 0.00 & 5.50 & 7.25 & 85.18 & 0.00 & 5.50 & 7.26 & 87.15 \\
\hline NAA 400ppm & 0.00 & 5.55 & 13.73 & 6.09 & 0.00 & 5.55 & 13.73 & 6.29 & 0.00 & 0.00 & 0.00 & 66.16 & 0.00 & 0.00 & 0.00 & 67.82 & 0.00 & 5.55 & 13.73 & 72.25 & 0.00 & 5.55 & 13.73 & 74.12 \\
\hline Urea $10 \%$ & 0.00 & 6.05 & $\mid 7.67$ & 13.88 & 0.00 & 7.46 & 7.67 & 14.23 & 0.00 & 0.00 & 0.00 & 83.32 & 0.00 & 0.00 & 0.00 & 80.46 & 0.00 & 6.05 & 7.67 & 97.20 & 0.00 & 7.46 & 7.67 & 94.70 \\
\hline Urea $15 \%$ & 0.00 & 5.05 & 6.69 & 14.32 & 0.00 & 5.05 & 6.69 & $\mid 14.76$ & 0.00 & 0.00 & 0.00 & 73.57 & 0.00 & 0.00 & 0.00 & $\mid 75.86$ & 0.00 & 5.05 & 6.69 & 87.89 & 0.00 & 5.05 & 6.69 & 90.62 \\
\hline $\begin{array}{l}\mathrm{ZnSO}_{4} 2 \%+ \\
\mathrm{NH}_{4} \mathrm{NO}_{3} 4 \%\end{array}$ & 0.00 & 5.11 & 11.37 & 8.55 & 0.00 & 5.11 & 11.37 & 8.71 & 0.00 & 0.00 & 0.00 & 76.53 & 0.00 & 0.00 & 0.00 & 77.99 & 0.00 & 5.11 & 11.37 & 85.08 & 0.00 & 5.11 & 11.37 & 86.71 \\
\hline ETH1200ppm & 0.00 & 7.46 & 7.21 & 11.83 & 0.00 & 6.05 & 7.21 & 12.11 & 0.00 & 0.00 & 0.00 & 85.25 & 0.00 & 0.00 & 0.00 & 87.22 & 0.00 & 7.46 & 7.21 & 97.08 & 0.00 & 6.05 & 7.21 & 99.33 \\
\hline Control & 0.00 & 7.49 & - & - & 0.00 & 6.86 & - & - & 0.00 & 81.34 & 100 & 100 & 0.007 & 76.55 & 100 & 100 & 0.00 & 88.84 & 100 & 100 & 0.00 & 83.41 & 100 & 100 \\
\hline L.S.D at $5 \%$ & 0 & 0.1666 & 3.242 & 3.405 & 0 & 1.636 & 3.242 & 3.489 & 0 & 2.173 & 1.385 & 2.784 & 0 & 0.954 & 1.385 & 3.090 & 0 & 2.876 & 3.242 & 3.829 & 0 & 1.864 & 3.242 & 4.307 \\
\hline
\end{tabular}

